Proc. Estonian Acad. Sci. Biol. Ecol., 2003, 52, 1, 55-72

\title{
On the mechanism of cellular death under photoexcitation of haematoporphyrin derivative
}

\author{
Vladimir Chekulayev, Igor Shevchuk*, and Lyudmila Chekulayeva \\ Institute of Chemistry, Tallinn Technical University, Akadeemia tee 15, 12618 Tallinn, Estonia \\ Received 7 February 2002, in revised form 11 September 2002
}

\begin{abstract}
The goal of this study was to estimate the importance of damage of lipids compared to proteins in the deterioration of plasma membrane integrity, the mitochondrial function, and cell killing by photodynamic therapy (PDT) with haematoporphyrin derivative (HPD). It was found that photoirradiation of Ehrlich ascites carcinoma (EAC) cells pre-incubated with HPD resulted in a considerable inhibition of their glycolytic and respiratory activity, decreasing substantially the adenosine triphosphate (ATP) content. The obtained results indicate a close relationship between the HPD-PDT induced disturbances of the energy metabolism of irradiated cells and their ability to survive, e.g. 20 min of light exposure caused an $80 \%$ decrease in the ATP level and inactivation of approximately $98 \%$ of the cells (as measured by MTT-assay). Other effects of HPD-PDT, such as an increased permeability of the outer membrane to trypan blue and the alterations in cell morphology (swelling, appearance of large protrusions on the cell surface), were observed at much larger light doses. Our studies showed that there is a very low probability that the phototoxic effects of HPD toward EAC cells, including mitochondrial, were mediated by the peroxidation of membrane lipids since only negligible amounts of oxidation products of unsaturated fatty acids were detected. Furthermore, the photosensitization of EAC cells by HPD had a minor effect on the intracellular content of cholesterol. However, we found that cellular proteins are very sensitive to the damaging influence of HPD-PDT; a clearly expressed decrease in the content of tryptophan, cysteine and, especially, histidine was registered. The HPD-photosensitized oxidation of proteins was associated with disruption of the cytoplasmic membrane and an inhibition of the mitochondrial function. Our data suggest that cellular proteins are the most critical targets upon photoexcitation of HPD.
\end{abstract}

Key words: photodynamic therapy, tumour, lipid peroxidation, proteins, blebbing, adenosine triphosphate, MTT-assay.

\begin{abstract}
Abbreviations: ATP = adenosine triphosphate; Cys = cysteine; DMSO = dimethyl sulphoxide; $\mathrm{EAC}=$ Ehrlich ascites carcinoma; GSH = reduced glutathione; His = histidine; HPD = haematoporphyrin derivative; $\mathrm{LND}=$ lonidamine; $\mathrm{MDA}=$ malondialdehyde; $\mathrm{MTT}=3$-(4,5-dimethylthiazol-2-yl)-2,5-diphenyltetrazolium bromide; ${ }^{1} \mathrm{O}_{2}=$ singlet oxygen; $\mathrm{PBS}=$ phosphate buffered saline; $\mathrm{PDT}=$ photodynamic therapy; $\mathrm{PrSH}=$ protein-associated sulfhydryl groups; $\mathrm{PS}=$ photosensitizer; PUFA = polyunsaturated fatty acids; $\mathrm{TB}=$ trypan blue; $\mathrm{TCA}=$ trichloroacetic acid; $\operatorname{Trp}=$ tryptophan.
\end{abstract}

*Corresponding author, igor@chemnet.ee 


\section{INTRODUCTION}

The porphyrin-photosensitized damage of mammalian cells is presently a subject of active research. This is largely motivated by new applications of these agents in such areas as photodynamic therapy (PDT) of cancer and other diseases. PDT is a rapidly expanding approach for treatment of malignant tumours involving the administration of a tumour-localizing photosensitizer (PS) and its subsequent activation by light, usually from a laser. Haematoporphyrin derivative (HPD) and its improved version, called Photofrin II, are still the most widely used PSs for PDT of cancer. Photoexcitation of HPD leads to the formation of singlet molecular oxygen $\left({ }^{1} \mathrm{O}_{2}\right)$, a highly reactive oxidant, which is reported to be the main agent responsible for induction of tumour necrosis (Weishaupt et al., 1976). A variety of different types of tumours in many locations have been treated with excellent results by PDT (e.g. Okunaka et al., 1990). However, in spite of the large amount of experimental data, the damaging processes directly responsible for cell death have been studied insufficiently. At the same time, the information on the mechanism of HPD-sensitized photokilling of neoplastic cells is needed for further development of more effective PDT protocols.

Being hydrophobic in character, HPD tends to localize in plasma and subcellular membranes, making these structures especially sensitive to the photooxidative damage. Namely, it was reported that photodynamic treatment of tumour cells with HPD induces extensive alterations in the cell morphology (Volden et al., 1981), inhibits various membrane transport systems (Penning et al., 1994), destructs cellular membranes and mitochondria (Tatsuta et al., 1984). Moreover, among the subcellular organelles mitochondria are considered to be critical targets for the cell killing induced by photoactivated HPD (Hilf et al., 1986; Oleinick et al., 2002). As known both of the two main constituents of cellular membranes, lipids and proteins, may be damaged by the photodynamic action of porphyrins. Studies from several laboratories suggest that lipids in the membranes are the most critical targets upon photoexcitation of HPD. Namely, it was demonstrated that photodynamic treatment of tumour cells by the porphyrin may cause peroxidative degradation of unsaturated fatty acyl groups and cholesterol (a process commonly referred to as lipid peroxidation) that correlates with alterations in membrane permeability, loss of its fluidity, and finally with cell death (Chen et al., 1986; Thomas \& Girotti, 1988, 1989; Buettner et al., 1993; Kelley et al., 1997). However, in these published works it has not been proven that such a photodamage to lipids is the main reason for cell inactivation, since the effects of PDT with HPD on the intactness of cellular proteins were not examined during the in vitro experiments. Furthermore, an analysis of the literature data showed that in most cases these investigations about HPD-sensitized photooxidation of membrane lipids were performed on leukaemia cells. At the same, it is well known that the content of polyunsaturated fatty acids (PUFA) of different cell lines can vary greatly (Bartoli et al., 1980). Therefore, it is of great interest to examine the importance of lipid peroxidation in HPD-PDT induced cytotoxicity using neoplastic cells of another histological type. Although ${ }^{1} \mathrm{O}_{2}$ is generally accepted to 
attack unsaturated lipids, another oxygenation target could be a protein molecule. There are some indications that cellular proteins are very sensitive to the photodynamic action of HPD. It was reported that photosensitization of tumour cells by HPD may cross-link membranous proteins (Moan \& Vistnes, 1986), decrease the activity of various enzymes (Hilf et al., 1986; Atlante et al., 1989; Gibson et al., 1989; Prinsze et al., 1991), and affect the $\mathrm{Na}^{+} / \mathrm{K}^{+}$-ATPase pump (Penning et al., 1994). Moreover, it was shown (Moan \& Vistnes, 1986) that in tumour cells a significant fraction of the photodrug is in close contact with proteins. Hence, in cell membranes the ${ }^{1} \mathrm{O}_{2}$ molecule has a much higher probability of reacting with proteins than with surrounding lipids. Hence, it might be expected that at HPD-PDT the photooxidative degradation of proteins, but not lipids, plays a key role in the initiation of cell death. However, this hypothesis needs experimental checking.

The main goal of this study was, therefore, to estimate the importance of damage to lipids compared to proteins in the deterioration of plasma membrane integrity, the mitochondrial function, and cell killing by PDT with HPD as a PS.

\section{MATERIALS AND METHODS}

\section{Chemicals}

HPD was prepared from haematoporphyrin IX dihydrochloride (Aldrich) by the original method of Lipson et al. (1961) as modified by Kessel et al. (1987). The obtained product was diluted with $0.9 \% \mathrm{NaCl}$ solution $(\mathrm{pH} 7.4)$ to a final porphyrin concentration of $5 \mathrm{mg} / \mathrm{mL}$, and stored in the dark at $-70^{\circ} \mathrm{C}$. Working solutions of HPD, at a concentration of $0.5 \mathrm{mg} / \mathrm{mL}$, were prepared immediately before use by further diluting the stock solution with a medium (see below). Lonidamine (LND), kindly supplied by Dr. Aristide Floride from F. Angelini Research Institute, Rome, Italy (Lot 41A), was dissolved in dimethyl sulphoxide (DMSO) up to $100 \mathrm{mM}$ and was used on the same day as prepared. Other chemicals (of analytical grade or better) were purchased from Sigma, St. Louis, USA, unless noted otherwise. In the work, all solutions, including HPD preparations, were sterilized by filtration through $0.22 \mu \mathrm{m}$ filter units.

\section{Animals and cells}

White, mongrel, three month old female mice obtained from the Institute of Experimental and Clinical Medicine (Tallinn, Estonia) were used in the experiments. The animals were fed ad libitum on standard pellets and had permanent access to water. Ehrlich ascites carcinoma (EAC) cells obtained from the Institute of Chemical Physics and Biophysics (Tallinn, Estonia) were maintained by intraperitoneal transplantation of $0.2 \mathrm{~mL}$ ascites fluid (about $2.5 \times 10^{7}$ cells) from mouse to mouse every 7 days. 


\section{Preparation of cell suspensions and the irradiation conditions}

Six to seven days old EAC cells were withdrawn from the sacrificed animals and resuspended in phosphate buffered saline (PBS) containing $154 \mathrm{mM} \mathrm{NaCl}$, $6.2 \mathrm{mM} \mathrm{KCl}, 5.55 \mathrm{mM}$ glucose, and $10 \mathrm{mM}$ sodium phosphate buffer ( $\mathrm{pH} 7.4$ ). The cells were centrifuged at $400 \times g$ for $5 \mathrm{~min}$ at $4{ }^{\circ} \mathrm{C}$ and washed twice with the same medium. The packed cells were resuspended in the PBS to get a concentration of $1.2 \times 10^{8}$ cells $/ \mathrm{mL}$ and kept in an ice bath until use. The washed cells were then diluted with PBS to a final concentration of $4 \times 10^{7}$ cells $/ \mathrm{mL}$ and incubated in plastic flasks (Nunclon) with $5 \mu \mathrm{g} / \mathrm{mL}$ HPD for $25 \mathrm{~min}$ in the dark at $37^{\circ} \mathrm{C}$. In a previous work (Chekulayev et al., 1998) we found that about $60 \%$ of the porphyrin initially added to the medium was associated with cells at the end of the incubation period. An $8 \mathrm{~mL}$ sample of the cell suspension was transferred into a $2 \times 2 \mathrm{~cm}$ quartz cuvette and a microstirring magnet was added. Further the cells were irradiated in air with stirring at $20 \pm 1{ }^{\circ} \mathrm{C}$.

In all the experiments a voltage regulated $1 \mathrm{~kW}$ xenon arc lamp equipped with a focusing optical system and glass filters (KS-10 together with SZS-25) to deliver the light at $630 \mathrm{~nm}$ (the range between 590 and $830 \mathrm{~nm}$ ) served as the radiation source. The infrared radiation was removed by a $4 \mathrm{~cm}$ water filter. The flux of light was focused as a spot $\left(2.54 \mathrm{~cm}^{2}\right)$ and directed on the front face of a quartz cuvette containing EAC cell suspension. The intensity of the emitted light at $630 \mathrm{~nm}$ was always $150 \mathrm{~mW}$ with a power density of $59 \mathrm{~mW} / \mathrm{cm}^{2}$, as measured by an IMO-2N radiometer (Russian Federation). In some experiments (when LND was used as a PS), the cells were also exposed to UV radiation $\left(\lambda_{\max }=330 \mathrm{~nm}\right.$, range $260-390 \mathrm{~nm}$ ). In this study, the intensity of UV radiation was $170 \mathrm{~mW}$ (fluence rate, $67 \mathrm{~mW} / \mathrm{cm}^{2}$ ).

\section{Cytotoxicity assay}

Immediately after photoirradiation, $20 \mu \mathrm{L}$ aliquots of the cell suspension $\left(4 \times 10^{7}\right.$ cells $\left./ \mathrm{mL}\right)$ were placed into separate wells of a 24-well plate (Nunclon) containing $1.5 \mathrm{~mL}$ Dulbecco's modified Eagles medium (from Gibco Laboratories, Paisley, Scotland), supplemented with $10 \%$ foetal calf serum and $8 \mu \mathrm{g} / \mathrm{mL}$ tylosin. The cells were then incubated for $16 \mathrm{~h}$ at $37^{\circ} \mathrm{C}$ in a humidified atmosphere of $5 \% \mathrm{CO}_{2}$ in air. After the incubation, cell viability was measured using the 3-(4,5-dimethylthiazol-2-yl)-2,5-diphenyltetrazolium bromide (MTT) method. This method is based on the reduction of MTT by the succinate dehydrogenase of the mitochondria (Mossman, 1983). For the determination of the dehydrogenase activity, the cells were transferred into test tubes and the culture medium was removed by centrifugation. After the addition of $0.5 \mathrm{~mL}$ of $2 \mathrm{mg} / \mathrm{mL}$ MTT solution (in Hanks' balanced salt solution, without phenol red, supplemented with $10 \mathrm{mM}$ Hepes buffer, $\mathrm{pH}$ 7.2), the cells were incubated for $3 \mathrm{~h}$ in a water bath at $37^{\circ} \mathrm{C}$. At the end of the incubation period, the tubes with samples were immersed in an ice bath for $5 \mathrm{~min}$, and the cells were harvested by centrifugation at $3000 \times g$ for 
$10 \mathrm{~min}$ at $4{ }^{\circ} \mathrm{C}$. The supernatant was carefully removed by aspiration and the pellet was dissolved in $3.0 \mathrm{~mL}$ DMSO. Absorbance of the samples was measured at $570 \mathrm{~nm}$. To calculate the fraction of surviving cells, the absorbance of the solution from treated cells was divided by the absorbance of the solution from control (no treatment) cells.

\section{Assessment of membrane permeability}

Trypan blue (TB) dye exclusion was used to determine membrane permeability. During the whole irradiation procedure $10 \mu \mathrm{L}$ aliquots of the cell suspension $\left(4 \times 10^{7}\right.$ cells $\left./ \mathrm{mL}\right)$ were removed every $5 \mathrm{~min}$ and mixed with $150 \mu \mathrm{L}$ TB solution $(0.1 \%$, in PBS). Then, $25 \mu \mathrm{L}$ of the mixture was transferred to a microscopic slide, covered with a cover slip, and observed microscopically. Next, 150 tumour cells were observed at random, and the proportion of TB-stained cells was determined.

\section{Assessment of mitochondrial function and glycolysis}

The integrity of mitochondria in EAC cells was estimated by measuring the rate of oxygen consumption by the cells $\left(1 \times 10^{7}\right.$ cells $/ \mathrm{mL}$, in air-saturated PBS) with a Clark-type oxygen electrode. The initial concentration of dissolved oxygen was $0.214 \mathrm{mM}$. The measurements were performed in a water-thermostatted incubation chamber under continuous magnetic stirring at $37^{\circ} \mathrm{C}$.

The rate of glycolysis was estimated by glucose consumption. EAC cells at a concentration of $1 \times 10^{7}$ cells $/ \mathrm{mL}$ were incubated for $1 \mathrm{~h}$ in a water bath $\left(37^{\circ} \mathrm{C}\right)$ in PBS. At the end of the incubation, $0.5 \mathrm{~mL}$ of $9 \%$ trichloroacetic acid (TCA) solution was added to $1 \mathrm{~mL}$ of cellular suspension. The samples were vortexed and stored for $1 \mathrm{~h}$ at $4{ }^{\circ} \mathrm{C}$. The cells were then sedimented by centrifugation at $3000 \times g$ for $10 \mathrm{~min}$ at $4^{\circ} \mathrm{C}$. The glucose concentration in the supernatant was measured colorimetrically by standard $o$-toluidine reagent using a "Sigma" Kit (procedure No. 635).

\section{Measurement of the intracellular content of ATP}

Immediately after HPD-PDT, adenosine triphosphate (ATP) was extracted from $1 \times 10^{6}$ cells by the addition of $0.1 \mathrm{~mL}$ of an ice-cold solution containing $5 \%$ TCA and $4 \mathrm{mM}$ ethylenediaminetetraacetic acid. The cell extracts were then assayed with luciferin/luciferase using a Luminometer 1251 (BioOrbit, Turku, Finland), essentially as described by Kahru et al. (1982).

\section{Assay for lipid peroxides}

Lipid peroxidation in EAC cells was assayed by two different methods. Malondialdehyde (MDA) and other aldehydic products of photooxidation were 
estimated colorimetrically with 2-thiobarbituric acid. Namely, during the whole irradiation procedure fractions of $0.4 \mathrm{~mL}$ cellular suspension $\left(16 \times 10^{6}\right.$ cells $)$ were collected into test tubes containing $1.2 \mathrm{~mL}$ PBS (without glucose). After addition of $0.8 \mathrm{~mL}$ of $15 \%$ TCA solution the samples were vortexed and stored on an ice bath for one hour. Then the suspension was centrifuged and $1 \mathrm{~mL}$ of $1 \%$ 2-thiobarbituric acid (in $0.05 \mathrm{M} \mathrm{NaOH}$ ) was added to $2 \mathrm{~mL}$ of the supernatant. The mixture was heated for $15 \mathrm{~min}$ at $100^{\circ} \mathrm{C}$, cooled, and MDA levels were measured by recording absorbance at $532 \mathrm{~nm}$ on a Specord M-40 spectrophotometer (Germany). The final concentration of MDA in the samples was calculated using a molar extinction coefficient of $1.56 \times 10^{5} \mathrm{M}^{-1} \mathrm{~cm}^{-1}$. Measurements were expressed in terms of MDA normalized to the cell protein content. The total cell proteins were determined by the method of Lowry et al. (1951), with bovine serum albumin as the standard. Conjugated dienes, i.e. primary products of the peroxidation of unsaturated fatty acids, were assayed according to Recknagel \& Ghoshal (1966). In this assay, $16 \times 10^{6}$ cells were extracted in $5 \mathrm{~mL}$ of chloroformmethanol 2:1 (v/v). The chloroform-methanol extract was forced into a two-phase system by addition of water. The recovered chloroform phase was evaporated to dryness over nitrogen at $40^{\circ} \mathrm{C}$. The lipid residues were redissolved in $3 \mathrm{~mL}$ methanol, vortexed for $30 \mathrm{sec}$, and the absorbance at $233 \mathrm{~nm}$ (ascribed to conjugated dienes) was recorded against a methanol blank. The concentration of conjugated dienes was calculated using a molar extinction coefficient of $2.52 \times 10^{4} \mathrm{M}^{-1} \mathrm{~cm}^{-1}$.

\section{Determination of the intracellular content of tryptophan, histidine, protein-associated sulfhydryl groups, reduced glutathione, and cholesterol}

Tryptophan (Trp) was measured by the method of Spies \& Chambers (1948). For each sample, $2 \times 10^{7}$ cells were collected in $1 \mathrm{~mL}$ PBS, and $9 \mathrm{~mL}$ of $22.3 \mathrm{mM}$ solution of $p$-dimethylaminobenzaldehyde in $21.1 \mathrm{~N} \mathrm{H}_{2} \mathrm{SO}_{4}$ was added (the Ehrlich reagent was prepared immediately before use). After $16 \mathrm{~h}$ at room temperature, $0.1 \mathrm{~mL}$ of $0.045 \% \mathrm{NaNO}_{2}$ solution was added, and 30 min later the absorbance was measured at $590 \mathrm{~nm}$.

The histidine (His) content of cellular proteins was estimated with 5-aminotetrazole according to the procedure of Sokolovsky \& Vallee (1966), whereas protein-associated sulfhydryl groups $(\mathrm{PrSH})$ were assayed by the method of Ellman with 5,5'-dithiobis-2-nitrobenzoic acid exactly as described in (Edwards, 1988).

Reduced glutathione (GSH) was assayed by the spectrofluorometric method of Hissin \& Hilf (1976). Briefly, GSH in the acid-soluble supernatant fraction of EAC cells was reacted with $o$-phthaldialdehyde (Fluka BioChemica, Germany) at $\mathrm{pH} 8$ to yield a highly fluorescent cyclic product; its fluorescence was measured by a Hitachi 650-60 fluorescence spectrophotometer (Japan). 
The content of total cholesterol in EAC cells was assessed colorimetrically by the reaction of Liberman and Burchard as described previously in (Prokhorova, 1982). For each estimation, $12 \times 10^{6}$ cells were used.

\section{RESULTS}

It was found that photodynamic treatment of EAC cells with HPD as a sensitizer led to significant alterations in the shape and dimensions of the cells. The following events took place: a two- to three-fold increase in the cell volume, the appearance of numerous small protrusions on the cell surface (also known as "blebs"), the blending of microblebs into large protrusions of cytoplasm. Some of these effects are shown in Fig. 1. However, control experiments showed that illumination of EAC cells not exposed to HPD or incubation of the cells with the PS in PBS in the dark did not cause similar abnormalities in the cell morphology.

In addition to morphologic changes, the cells were tested for membrane permeability that can be detected by TB dye uptake (cells whose membranes are intact, exclude TB; when the membrane is damaged, TB can enter the cell). As shown in Fig. 2a, the uptake of TB by EAC cells pre-incubated with HPD increased slowly within $20 \mathrm{~min}$ of photoirradiation. Longer illumination of the cells induced a burst in the uptake of TB. At a later stage (after a $45 \mathrm{~min}$ irradiation) the appearance of ruptures on the outer membrane was also observed. By contrast, the TB uptake remained negligible in EAC cells incubated with HPD alone, as well as in cells irradiated in the absence of the PS.

According to our results the photoirradiation of EAC cells pre-incubated with HPD resulted in a serious damage of their mitochondria. In fact, after a $40 \mathrm{~min}$ illumination a considerable (approximately 90\%) decrease in the rate of oxygen consumption by the cells was observed (Fig. 2b). Furthermore, the HPD-based PDT led to a substantial inhibition of the glycolytic activity of EAC cells (Fig. 2c). These events were associated with a dramatic (approximately $80 \%$ )
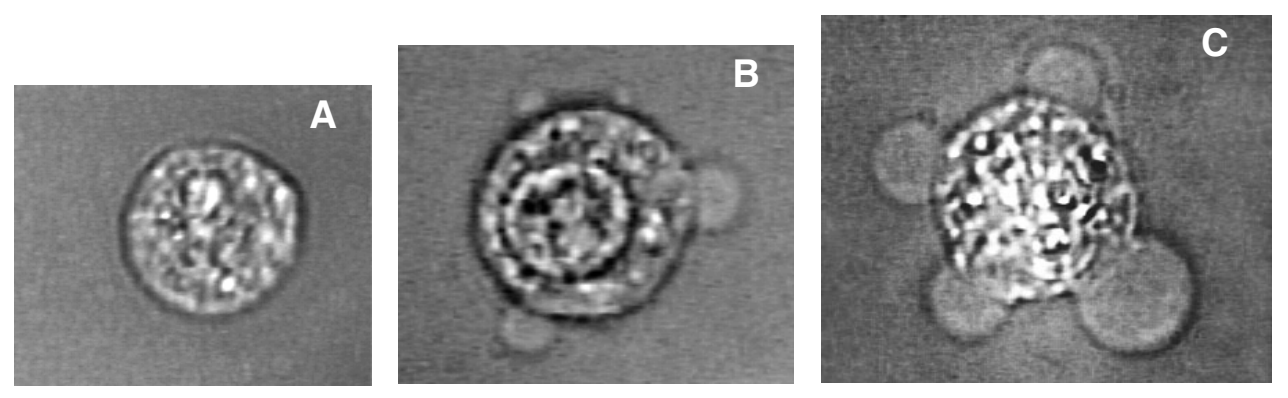

Fig. 1. Phase-contrast microphotographs of EAC cells before (A) and $45 \mathrm{~min}$ after (B and C) their photoirradiation with $5 \mu \mathrm{g} / \mathrm{mL}$ HPD. 

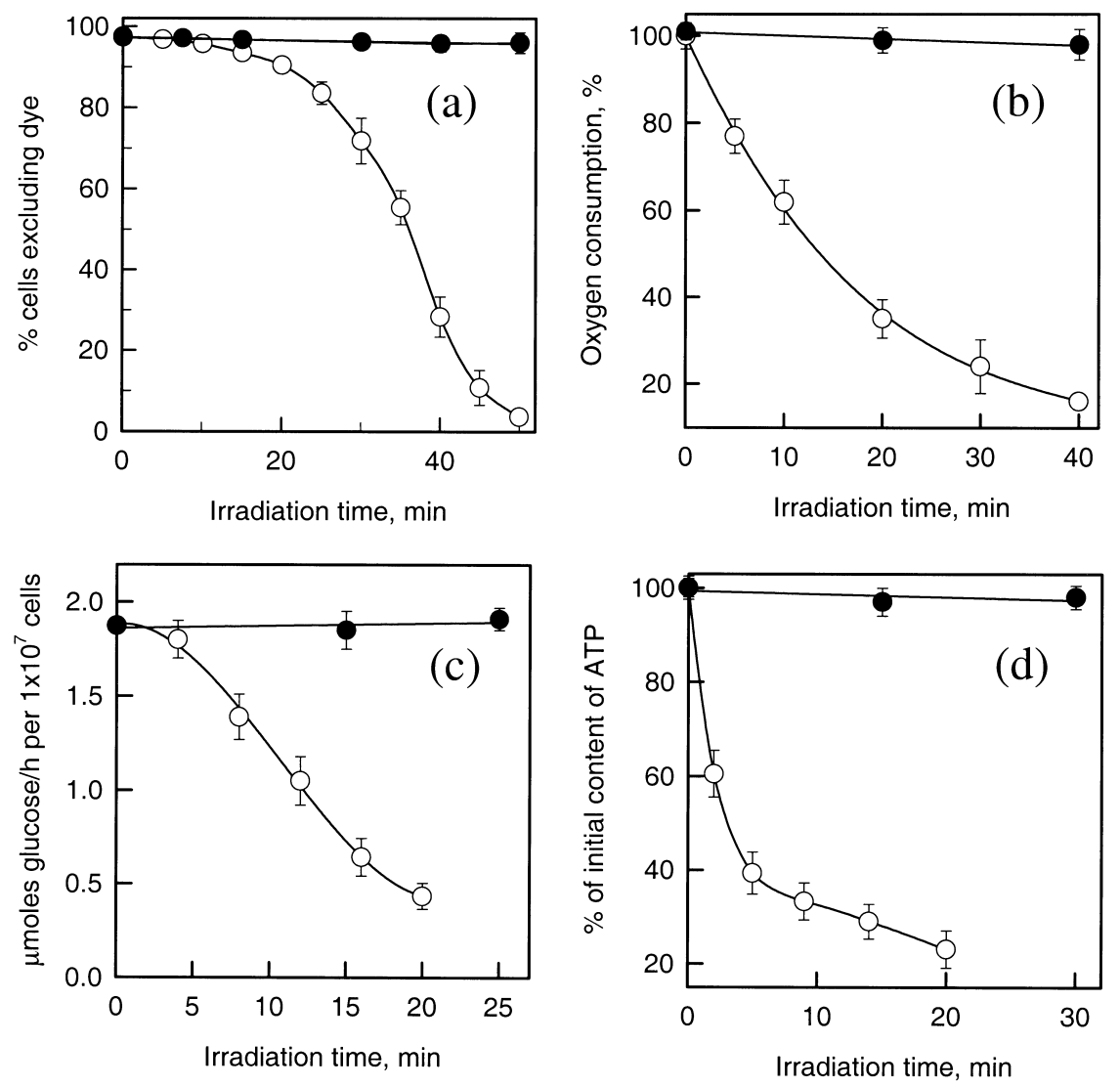

Fig. 2. The kinetics of trypan blue-staining (a), oxygen consumption (b), glycolytic activity (c), and the ATP content (d) of EAC cells during their photoirradiation in the presence of $5 \mu \mathrm{g} / \mathrm{mL}$ HPD (open symbols) or at the dark incubation with the drug (filled symbols). The initial rate of oxygen consumption by the nonirradiated cells was measured as $1.42 \pm 0.06 \mathrm{nmoles} \mathrm{O}_{2} / \mathrm{min}$ per $1 \times 10^{6}$ cells. The initial level of ATP in the cells was $3.62 \pm 0.24$ nmoles per $1 \times 10^{6}$ cells. Points with SE bars show means of at least three separate experiments.

fall in the intracellular content of ATP (Fig. 2d). Thus the HPD-induced photosensitization caused a strong damage not only to the cytoplasmic membrane but also to the energy homeostasis of EAC cells. It was also established that all these disturbances to the energy metabolism preceded the disintegration of the outer membrane in the cells.

Using the MTT-assay we also estimated the in vitro phototoxicity of PDT towards EAC cells. It was found that irradiation of HPD-treated cells with $20 \mathrm{~min}$ light exposure led to a significant (approximately 98\%) decrease in the number of surviving cells (Fig. 3). However, neither HPD nor light alone in the doses used had any effect on the viability of the cells. 


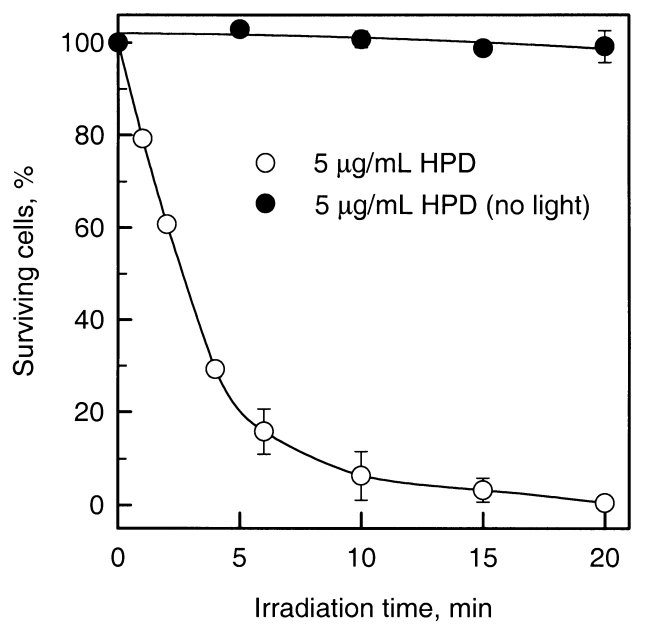

Fig. 3. The viability of EAC cells, as estimated by the MTT-assay, after their photodynamic treatment with HPD. All the data are from three independent experiments performed in duplicate. Bars, SE.

To elucidate the role of damage to membrane lipids in PDT-induced cytotoxicity, the effects of light exposure with HPD on the oxidation of PUFA and cholesterol in EAC cells were examined. Figure 4 shows that photosensitization of the cells by the porphyrin resulted in an enhancement of lipid peroxidation expressed as a gradual increase in the concentration of conjugated dienes and MDA. Nevertheless, only very small amounts of these products of lipid peroxidation were found even after a prolonged $(50 \mathrm{~min})$ illumination of the tumour cells. This was surprising as the photodynamic treatment of EAC with HPD caused a strong decrease in the intracellular content of GSH (Fig. 5), which, as known, jointly with some GSH-dependent enzymes plays an important role in the detoxification of the formed lipoperoxides. A possible explanation for the phenomenon might be that the membranous phospholipids of EAC cells are characterized by a higher concentration of saturated fatty acids. However, further experiments showed that the cells contain a sufficient amount of the photooxidizable PUFA. Indeed, the treatment of EAC cells with $0.25 \mathrm{mM}$ LND, an antitumour agent having photosensitizing activity (Chekulayev et al., 1997), for $10 \mathrm{~min}$ followed by $50 \mathrm{~min}$ exposure to UV light $\left(\lambda_{\max }=330 \mathrm{~nm}\right)$ induced a 6-fold increase in the formation of MDA (Fig. 4). It was also found that photodynamic treatment of EAC cells by HPD had a minor effect on the cholesterol content of the cells (Fig. 5).

One of the mechanisms by which tumour cells might be damaged during the HPD-based PDT may include direct oxidation of their proteins by photodynamically generated ${ }^{1} \mathrm{O}_{2}$. Therefore, we evaluated the intactness of proteins in EAC cells after their irradiation with the PS. As shown in Fig. 5, the photodynamic treatment of the cells by HPD resulted in a substantial modification of the amino acid composition of their proteins; namely, the part of photooxidized 


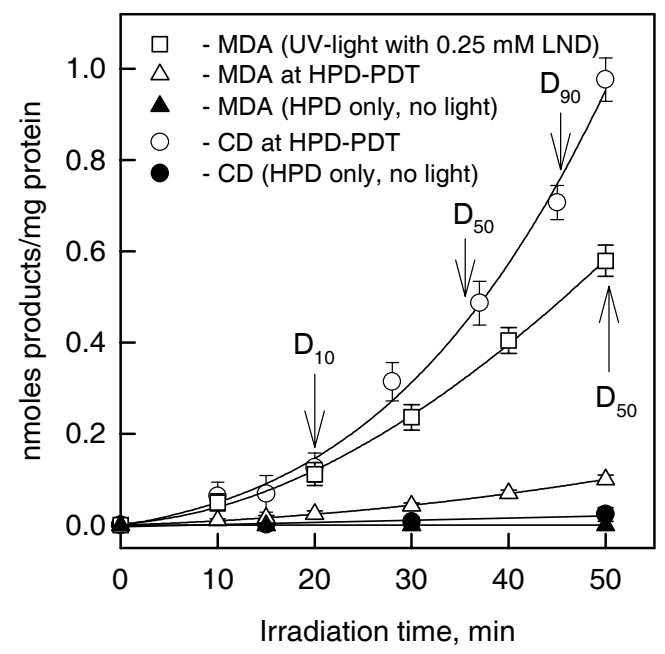

Fig. 4. Lipid peroxidation in EAC cells exposed to HPD- or LND-induced photosensitization as a function of time. MDA, malondialdehyde; $C D$, conjugated dienes; $\mathrm{D}_{10}, \mathrm{D}_{50}$, and $\mathrm{D}_{90}$ are the light doses at which $10 \%, 50 \%$, and $90 \%$ of the cells were stained by trypan blue. The content of CD in control cells was measured as $0.81 \pm 0.04 \mathrm{nmoles} / \mathrm{mg}$ protein and the value was subtracted from those found in photodynamically treated cells. LND was added to EAC cells $10 \mathrm{~min}$ prior to the UV irradiation. All data are from three independent experiments. Bars, SE.

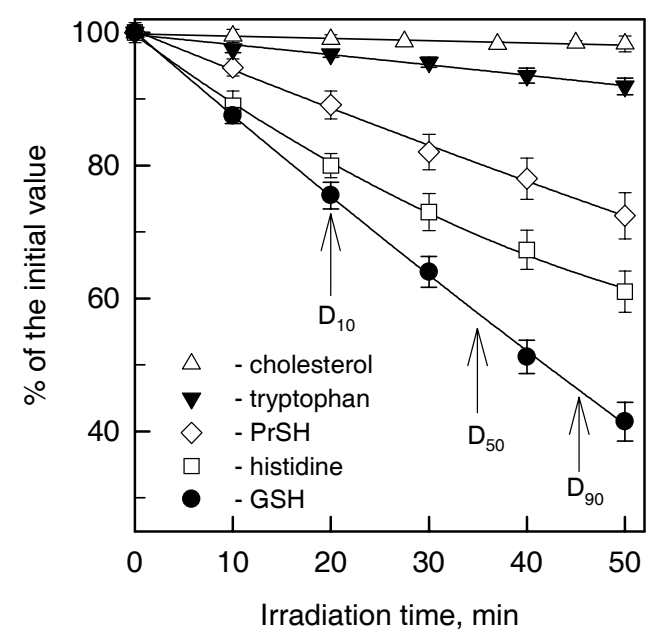

Fig. 5. Effects of HPD-induced photosensitization on the cholesterol, tryptophan, protein-associated SH groups (PrSH), histidine, and reduced glutathione (GSH) content of EAC cells. $\mathrm{D}_{10}, \mathrm{D}_{50}$, and $\mathrm{D}_{90}$ are the light doses at which $10 \%, 50 \%$, and $90 \%$ of the cells were stained by trypan blue. The points with error bars refer to three independent experiments. The initial level of GSH in the cells was measured as $1.41 \pm 0.07$ nmoles per $1 \times 10^{6}$ cells. 
amino acid residues after 50 min illumination was determined as $8 \%$ for Trp, $39 \%$ for His, and $28 \%$ for PrSH. By contrast, a prolonged incubation of EAC cells with the PS in PBS in the dark or photoirradiation of the cells not exposed to HPD did not induce similar changes (data not shown).

\section{DISCUSSION}

Our experiments demonstrated that photosensitization of EAC cells by HPD causes a strong inhibition of their glycolytic and respiratory activity, and substantially decreases the ATP content (Fig. 2). Furthermore, in our previous studies (Chekulayev et al., 2000) we showed that under the same experimental conditions the photoirradiation of EAC cells with HPD led to a very rapid and drastic decrease in the activity of succinate dehydrogenase, a marker mitochondrial enzyme. Other effects of HPD-PDT, such as an increased permeability of the plasma membrane to $\mathrm{TB}$ and the alterations in cell morphology (swelling, appearance of large protrusions on the cell surface), were observed at much larger light doses. The obtained results indicate a close relationship between HPD-PDT induced disturbances of the energy metabolism of irradiated cells and their ability to survive; for example, $20 \mathrm{~min}$ of light exposure caused an $80 \%$ decrease in the ATP level and inactivation of approximately $98 \%$ of the cells (Figs. 2d and 3). The findings suggest that after PDT with HPD the carcinoma cells died mainly via the injury of their mitochondria as well as some glycolytic enzymes. Our results are in good agreement with the data of other researchers (Hilf et al., 1986; Atlante et al., 1989; Penning et al., 1994), who consider that inhibition of the mitochondrial function may be a crucial event in the cytotoxicity resulting from HPD-induced photosensitization in vitro.

In the present study we found that photoirradiation of EAC cells pre-incubated with HPD resulted in an enhancement of lipid peroxidation and caused a serious damage to cellular proteins. These molecular changes were associated with disturbances in the cell morphology, an increased permeability of the outer membrane to TB, an inhibition of the mitochondrial function, and cell photokilling. What is the significance of HPD-sensitized photooxidation of cellular lipids in the phototoxic effects of the photodrug? It is well documented that the oxidative degradation of PUFA and cholesterol is detrimental to membrane structures and functions. Indeed, when the lipids are peroxidized, the membranes, which consist of lipids and proteins, undergo a physical change and are finally destroyed. Moreover, it was also established that in the presence of certain transition metal ions the break-down of lipid hydroperoxides via a radical chain reaction produces reactive oxygen species, various aldehydes, and other toxic products that can modify proteins and DNA and lead to cell death (Paillous \& Forgues-Ferry, 1994; Girotti, 2001). It was suggested that lipid peroxidation may be causally related to cytolethality in HPD-photosensitized cells. Namely, Thomas \& Girotti (1989) showed using murine leukaemia cells that photodynamic treatment of the cells by 
HPD resulted in the formation of large amounts of lipid hydroperoxides. These authors concluded that lipid peroxidation plays an important role in tumour cell eradication. Buettner et al. (1993), using leukaemia cells of the same line (L1210), showed that PDT with Photofrin ${ }^{\circledR}$ produces membrane-derived lipid free radicals and that increasing the polyunsaturation of cellular lipids enhances radical production as well as the resulting phototoxicity. Furthermore, this research group reported (Kelley et al., 1997) that under PDT with Photofrin ${ }^{\circledR}$ the presence of iron and ascorbic acid accelerates this free radical formation and that the event correlates with an increase in TB-detectable membrane leakage and cell disintegration. By contrast, our experiments on EAC cells indicated that there is a very low probability that the HPD-PDT induced impairment of the mitochondrial function and, as a consequence, cell death were mediated by the peroxidation of membrane lipids. In fact, after $20 \mathrm{~min}$ of light exposure, which caused a substantial (more than 2-fold) decrease in the respiratory activity of the cells as well as a $98 \%$ decrease in cell survival, only traces of oxidation products of unsaturated fatty acids were detected (Figs. 2b, 3, and 4, respectively). Furthermore, the photodynamic treatment of EAC with HPD (for $20 \mathrm{~min}$ ) had no effect on the intracellular content of cholesterol (Fig. 5). Nevertheless, we cannot exclude entirely the importance of lipid peroxidation in the PDT-induced deterioration of the plasma membrane integrity in EAC cells.

At the same time, we found that in EAC cells proteins are much more sensitive to the damaging influence of HPD-PDT than their lipid constituents. Namely, in the cells the initial rates of HPD-photosensitized oxidation of PrSH, Trp, and His residues were more than 10 times as high as those for unsaturated lipids (Table 1). What is the mechanism of the phenomenon? In cell membranes, lipids and proteins provide a competing environment for the formed ${ }^{1} \mathrm{O}_{2}$. However, as

Table 1. The oxidation rates of unsaturated lipids, proteins, and some amino acids in solution as well as in EAC cells subjected to HPD-induced photosensitization in vitro

\begin{tabular}{l|c|c|c}
\hline Component & $\begin{array}{c}\text { Initial level in nonirradiated } \\
\text { cells, nmoles per } 1 \times 10^{6} \text { cells } \\
( \pm \mathrm{SE})\end{array}$ & $\begin{array}{c}\text { Initial rate of photo- } \\
\text { oxidation, nmoles } \mathrm{h}^{-1} \\
\text { per } 1 \times 10^{6} \text { cells }( \pm \mathrm{SE})\end{array}$ & $k_{\mathrm{r}}, \mathrm{M}^{-1} \mathrm{~s}^{-1}$ \\
\hline & & $0.010 \pm 0.001^{\mathrm{a}}$ & $0.74-2.4 \times 10^{5 \mathrm{c}}$ \\
Unsaturated fatty acids & - & $0.051 \pm 0.008^{\mathrm{b}}$ & $0.67 \times 10^{5 \mathrm{c}}$ \\
Cholesterol & $16.54 \pm 0.84$ & $0.34 \pm 0.12$ & $3.6 \times 10^{7 \mathrm{~d}}$ \\
Tryptophan & $22.34 \pm 1.03$ & $1.97 \pm 0.21$ & $5 \times 10^{7 \mathrm{e}}$ \\
Histidine & $53.7 \pm 3.8$ & $35.2 \pm 1.9$ & $0.89 \times 10^{7 \mathrm{f}}$ \\
Cysteine & $17.05 \pm 0.68$ & $6.14 \pm 0.64$ & $2-5 \times 10^{8 \mathrm{~g}}$ \\
Albumin & - & - &
\end{tabular}

Notes: ${ }^{\mathrm{a}}$ - this value was calculated by measuring the formation of MDA, and ${ }^{\mathrm{b}}$ - by measuring the production of conjugated dienes; $k_{\mathrm{r}}$ - rate constants of ${ }^{1} \mathrm{O}_{2}$ reactions with different substrates in solution: ${ }^{\mathrm{c}}$ from (Doleiden et al., 1974), ${ }^{\mathrm{d}}$ from (Reddi et al., 1984), ${ }^{\mathrm{e}}$ from (Kraljic \& Sharpatyi, 1978), ${ }^{\mathrm{f}}$ from (Rougee et al., 1988), ${ }^{\mathrm{g}}$ from (Wilkinson et al., 1995). 
known proteins are more reactive toward ${ }^{1} \mathrm{O}_{2}$ than unsaturated lipids. As shown in Table 1, the typical rate constants reported for unsaturated lipids (PUFA and cholesterol) reacting with ${ }^{1} \mathrm{O}_{2}$ in organic solvents are of the order of $10^{5} \mathrm{M}^{-1} \mathrm{~s}^{-1}$. In contrast, rate constants for ${ }^{1} \mathrm{O}_{2}$ reacting with photooxidizable amino acids and proteins are considerably greater, $10^{7}-10^{8} \mathrm{M}^{-1} \mathrm{~s}^{-1}$. Moreover, Kanofsky (1991) showed that only approximately $7 \%$ of the ${ }^{1} \mathrm{O}_{2}$ produced in membranes is quenched by cellular lipids. This is in agreement with our data, which suggest that lipids may not be the primary target for HPD-PDT-induced cytotoxicity in vitro.

In this work we demonstrated that photoirradiation of EAC cells in the presence of HPD resulted in a serious damage of their proteins. It was also established that in cellular proteins the Cys and, especially, His residues degrade more easily than the Trp (Fig. 5). Trp is a well-known compound in photochemistry and can be easily oxidized by HPD plus light in model experiments (Reddi et al., 1984). In our experiments with EAC cells, however, it was destroyed only slightly (by $8 \%$ ), although in aqueous solution the rate constant for ${ }^{1} \mathrm{O}_{2}$ reacting with Trp exceeds considerably that for Cys (Table 1). Hence, it seems likely that not all of the Trp molecules can be reached by excited HPD. Taken together, our results suggest that at HPD-PDT the direct photodamage of cellular proteins, but not the peroxidation of membrane lipids, is responsible for cell death. In fact, at a light dose that kills about $98 \%$ of EAC cells (Fig. 3) only traces of PUFA and cholesterol were oxidized, but SH groups and His residues of proteins appeared to be very sensitive targets: of the His and PrSH content, 20\% and $12 \%$ was destroyed respectively during the PDT with HPD (Figs. 4 and 5). Moreover, by the experimental protocol utilized in the work, the mechanism of some cytotoxic effects of HPD-PDT might be uncovered to some degree.

It was found (Fig. 1) that photodynamic treatment of EAC cells by HPD resulted in the appearance of numerous plasma membrane protrusions (blebs). Similar changes in cell morphology after HPD-induced photosensitization were also registered in other laboratories (Volden et al., 1981). However, the mechanism of bleb formation and its significance in cell death remain unclear as yet, especially in the case of PDT-induced cytotoxicity. In our experiment on EAC cells the formation of blebs was usually associated with intensive staining of the cells by TB. Literature data suggest that under the PDT with HPD the appearance of large blebs on the surface of tumour cells might be associated with cytoskeletal abnormalities, in particular, with detachment of cortical (actin-containing) microfilaments from plasma membrane. Indeed, Fingar \& Wieman (1992) showed that photoirradiation of HPD-loaded endothelial cells results in disruption of their microfilament organization. Our findings, in turn, suggest that a decrease in the intracellular content of ATP (Fig. 2d) and the oxidation of PrSH (Fig. 5) might be responsible for the cytoskeletal disturbances produced by HPD-PDT. In fact, the formation of blebs was observed in the energy depleted EL-4 thymoma ascites tumour cells after their treatment with rotenone (an inhibitor of respiration) (Gabai et al., 1992). On the other hand, the same morphological changes were found in cells exposed to toxic levels of menadione (2-methyl-1,4-naphthoquinone) 
(Mirabelli et al., 1988). These researchers showed that the oxidation of thiol groups in cytoskeletal proteins (particularly, actin) is mainly responsible for menadione-induced cell surface abnormalities. At the same time, we found that during HPD-PDT the number EAC cells with blebs was inversely related with their PrSH content (Fig. 6).

The ability of photoexcited porphyrins to damage proteins is well documented. In tumour cells, such a photodamage to proteins, besides the peroxidation of unsaturated lipids, can lead to a severe injury and, as a consequence, to cell death. So, in our experiments the HPD-PDT-induced violation of the plasma membrane integrity (as evaluated by TB-test) was directly related with a decrease in the Trp, His, and PrSH content (Fig. 5). This observation is in agreement with the suggestion of Dubbelman et al. (1978) that the main photodynamic effect of porphyrins on red cell membranes is caused by the photooxidation of amino acid residues of proteins, mainly His. In the study, we also found that photodynamic treatment of EAC cells with HPD caused a strong reduction in the intracellular level of ATP, which preceded the disintegration of the outer membrane in the cells (Fig. 2). Because in mammalian cells practically all vital functions are dependent on the presence of ATP, we believe that upon HPD-PDT the shortage of energy could contribute to the TB-detectable membrane leakage. Our findings suggest that after PDT with HPD the EAC cells died mainly via the inactivation of their energy producing systems; a powerful inhibition of the mitochondrial function as well as of the glycolytic activity of the cells was registered (Fig. 2). The destructive impact of HPD-PDT was associated with oxidation of the PrSH (Fig. 5) and could be consequently ascribed to the inactivation of some enzymes containing in their active sites SH groups. Indeed, it was reported (Atlante et al., 1989) that oxidation of SH groups in the ADP/ATP translocator is the main cause

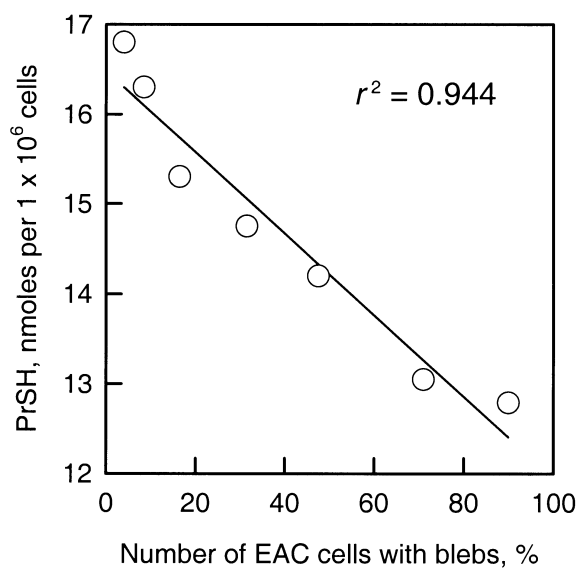

Fig. 6. The interrelationship between the number of EAC cells with blebs and their protein-associated $\mathrm{SH}$ groups $(\mathrm{PrSH})$ content. The cells $\left(4 \times 10^{7}\right.$ cells $/ \mathrm{mL}$ in PBS) were exposed to $5 \mu \mathrm{g} / \mathrm{mL}$ HPD-PDT. The total light exposure time was $45 \mathrm{~min}$. 
of oxidative phosphorylation impairment when isolated mitochondria are exposed to HPD and light. Moreover, the strong inhibition of glucose consumption by EAC cells (Fig. 2c) could be also explained via the HPD-photosensitized oxidation of PrSH since certain glycolytic enzymes contain, as known, in their active sites thiol groups. In fact, a significant decrease in the activity of glyceraldehyde-3phosphate dehydrogenase after photodynamic treatment of tumour cells with HPD was registered before by others (Prinsze et al., 1991).

\section{CONCLUSIONS}

Today, the prevalent concept is that under HPD-PDT the peroxidation of membrane lipids plays a crucial role in the initiation of cell death, although the ability of photoexcited HPD to damage a number of cellular proteins is also a well-documented fact. The work is apparently the first, known from the literature, attempt to determine the significance of photodamage of lipids compared to that of proteins in the photodynamic killing of tumour cells with HPD as a PS. Our in vitro experiments performed on EAC cells showed that cellular proteins, but not membrane lipids, are a principal target of PDT with the PS. Nevertheless, a comparison of our results with those from other laboratories (Thomas et al., 1989; Buettner et al., 1993; Kelley et al., 1997) suggests that upon HPD-PDT the significance of lipid peroxidation in the initiation of cell death may be dependent on the cell type. This hypothesis will be the subject of future studies. Our findings indicated that after PDT with HPD the EAC cells died mainly via the inactivation of their energy producing systems and that the PDT caused serious alterations in cell morphology (the appearance of numerous surface blebs). However, further work is required to clarify the mechanism of cell surface blebbing.

\section{REFERENCES}

Atlante, A., Passarella, S., Quagliariello, E., Moreno, G. \& Salet, C. 1989. Haematoporphyrin derivative (Photofrin II) photosensitization of isolated mitochondria: inhibition of ADP/ATP translocator. J. Photochem. Photobiol. B: Biol., 4, 35-46.

Bartoli, G. M., Bartoli, S., Galeotti, T. \& Bertoli, E. 1980. Superoxide dismutase content and microsomal lipid composition of tumors with different growth rates. Biochim. Biophys. Acta, 620, 205-211.

Buettner, G. R., Kelley, E. E. \& Burns, C. P. 1993. Membrane lipid free radicals produced from L1210 murine leukemia cells by photofrin photosensitization: an electron paramagnetic resonance spin trapping study. Cancer Res., 53, 3670-3673.

Chekulayev, V., Shevchuk, I., Chekulayeva, L. \& Kahru, A. 1997. Study of the photochemical and phototoxic properties of Lonidamine [1-(2,4-dichlorobenzyl)-1H-indazol-3-carboxylic acid]. J. Photochem. Photobiol. B: Biol., 41, 11-21.

Chekulayev, V., Shevchuk, I. \& Chekulayeva, L. 1998. Effects of light exposure on the uptake and destruction of hematoporphyrin derivative in Ehrlich carcinoma cell suspension. Proc Estonian Acad. Sci. Chem., 47, 73-91. 
Chekulayev, V., Shevchuk, I., Chekulayeva, L. \& Jäälaid, R. 2000. Influence of extracellular magnesium on the antitumour efficiency of photodynamic therapy. Proc. Estonian Acad. Sci. Chem., 49, 216-233.

Chen, Y. Q., Wang, J., Liu, Y. Z. \& Yu, S. Y. 1986. Mechanism of cell damage by hematoporphyrin derivatives (HPD) plus light. I. Photooxidation of hepatoma cell membrane by HPD plus light. Zhonghua Zhong Liu Za Zhi, 8, 413-416.

Doleiden, F. H., Fahrenholtz, S. R., Lamola, A. A. \& Trozzolo, A. M. 1974. Reactivity of cholesterol and some fatty acids toward singlet oxygen. Photochem. Photobiol., 20, 519-521.

Dubbelman, T. M. A. R., De Goeij, A. F. P. M. \& van Steveninck, J. 1978. Photodynamic effects of protoporphyrin on human erythrocytes. Nature of the cross-linking of membrane proteins. Biochim. Biophys. Acta, 511, 141-151.

Edwards, P. G. 1988. Evidence that glutathione may determine the differential cell-cycle phase toxicity of a platinum(IV) antitumor agent. JNCI, 80, 734-738.

Fingar, V. H. \& Wieman, J. F. 1992. Mechanisms of vessel damage in photodynamic therapy. Proc. SPIE, 1645, 98-103.

Gabai, V. L., Kabakov, A. E. \& Mosin, A. F. 1992. Association of blebbing with assembly of cytoskeletal proteins in ATP-depleted EL-4 ascites tumour cells. Tissue \& Cell, 24, 171-177.

Gibson, S. L., Murant, R. S., Chazen, M. D., Kelly, M. E. \& Hilf, R. 1989. In vitro photosensitization of tumour cell enzymes by Photofrin II administered in vivo. Br. J. Cancer, 59, 47-53.

Girotti, A. W. 2001. Photosensitized oxidation of membrane lipids: reaction pathways, cytotoxic effects, and cytoprotective mechanisms. J. Photochem. Photobiol. B: Biol., 63, 103-113.

Hilf, R., Murant, R. S., Narayanan, U. \& Gibson, S. L. 1986. Relationship of mitochondrial function and cellular adenosine triphosphate levels to hematoporphyrin derivative-induced photosensitization in R3230AC mammary tumors. Cancer Res., 46, 211-217.

Hissin, P. J. \& Hilf, R. 1976. A fluorometric method for determination of oxidized and reduced glutathione in tissues. Anal. Biochem., 74, 214-226.

Kahru, A., Liiders, M., Vanatalu, K. \& Vilu, R. 1982. Adenylate energy charge during batch culture of Thermoactinomyces vulgaris. Arch. Microbiol., 133, 142-144.

Kanofsky, J. R. 1991. Quenching of singlet oxygen by human red cell ghosts. Photochem. Photobiol., 53, 93-99.

Kelley, E. E., Buettner, G. R. \& Burns, C. P. 1997. Production of lipid-derived free radicals in L1210 murine leukemia cells is an early oxidative event in the photodynamic action of Photofrin ${ }^{\circledR}$. Photochem. Photobiol., 65, 576-580.

Kessel, D., Thompson, P., Musselman, B. \& Chang, C. K. 1987. Chemistry of hematoporphyrinderived photosensitizers. Photochem. Photobiol., 46, 563-568.

Kraljic, I. \& Sharpatyi, V. A. 1978. Determination of singlet oxygen rate constants in aqueous solutions. Photochem. Photobiol., 28, 583-586.

Lipson, R., Baldes, E. \& Olsen, A. 1961. The use of a derivative of hematoporphyrin in tumor detection. JNCI, 26, 1-8.

Lowry, O. H., Rosebrough, N. J., Farr, A. L. \& Randall, R. J. 1951. Protein measurement with the Folin phenol reagent. J. Biol. Chem., 193, 265-275.

Mirabelli, F., Salis, A., Perotti, M., Taddei, F., Bellomo, G. \& Orrenius, S. 1988. Alterations of surface morphology caused by the metabolism of menadione in mammalian cells are associated with the oxidation of critical sulfhydryl groups in cytoskeletal proteins. Biochem. Pharmacol., 37, 3423-3427.

Moan, J. \& Vistnes, A. 1986. Porphyrin photosensitization of proteins in cell membranes as studied by spin-labeling and by quantification of DTNB-reactive SH-groups. Photochem. Photobiol., 44, 15-19.

Mossman, T. 1983. Rapid colorimetric assay for cellular growth and survival: application to proliferation and survival assays. J. Immunol. Methods, 65, 55-63.

Okunaka, T., Kato, H., Conaka, C., Yamamoto, H., Bonaminio, A. \& Eckhauser, M. L. 1990. Photodynamic therapy of esophageal carcinoma. Surg. Endosc., 4, 150-153. 
Oleinick, N. L., Morris, R. L. \& Belichenko, I. 2002. The role of apoptosis in response to photodynamic therapy: what, where, why, and how. Photochem. Photobiol. Sci., 1, 1-21.

Paillous, N. \& Forgues-Ferry, S. 1994. Interest of photochemical methods for induction of lipid peroxidation. Biochimie, 76, 355-368.

Penning, L. C., Tijssen, K., Boegheim, J. P. J., van Steveninck, J. \& Dubbelman, T. M. A. R. 1994. Relationship between photodynamically induced damage to various cellular parameters and loss of clonogenicity in different cell types with hematoporphyrin as sensitizer. Biochim. Biophys. Acta, 1221, 250-258.

Prinsze, C., Dubbelman, T. M. A. R. \& van Steveninck, J. 1991. Potentiation of thermal inactivation of glyceraldehyde-3-phosphate dehydrogenase by photodynamic treatment. A possible model for the synergistic interaction between photodynamic therapy and hyperthermia. Biochem. J., 276, 357-362.

Prokhorova, M. I. 1982. Methods of Biochemical Studies. Leningrad, I LGU (in Russian).

Recknagel, R. O. \& Ghoshal, A. K. 1966. Lipoperoxidation of rat liver microsomal lipids induced by carbon tetrachloride. Nature, 210, 1162-1163.

Reddi, E., Rodgers, M. A. J., Spikes, J. D. \& Jori, G. 1984. The effect of medium polarity on the hematoporhyrin-sensitized photooxidation of L-tryptophan. Photochem. Photobiol., 40, 415-421.

Rougee, M., Bensasson, R. V., Land, E. J. \& Pariente, R. 1988. Deactivation of singlet molecular oxygen by thiols and related compounds, possible protectors against skin photosensitivity. Photochem. Photobiol., 47, 485-489.

Sokolovsky, M. \& Vallee, B. 1966. The reaction of diazonium-1H-tetrazole with proteins. Determination of tyrosine and histidine content. Biochemistry, 5, 3574-3581.

Spies, J. R. \& Chambers, D. C. 1948. Chemical determination of tryptophan. Anal. Chem., 20, 30-39.

Tatsuta, M., Yamamoto, R., Yamamura, H., Iishi, H., Noguchi, S., Ichii, M. \& Okuda, S. 1984. Photodynamic effects of exposure to hematoporphyrin derivatives and dye-laser radiation on human gastric adenocarcinoma cells. JNCI, 73, 59-67.

Thomas, J. P. \& Girotti, A. W. 1988. Photooxidation of cell membranes in the presence of hematoporphyrin derivative: reactivity of phospholipid and cholesterol hydroperoxides with glutathione peroxidase. Biochim. Biophys. Acta, 962, 297-307.

Thomas, J. P. \& Girotti, A. W. 1989. Role of lipid peroxidation in hematoporphyrin derivativesensitized photokilling of tumor cells: protective effects of glutathione peroxidase. Cancer Res., 49, 1682-1686.

Volden, G., Christensen, T. \& Moan, J. 1981. Photodynamic membrane damage of hematoporphyrin derivative-treated NHIK 3025 cells in vitro. Photobiochem. Photobiophys., 3, 105-111.

Weishaupt, K. R., Gomer, C. J. \& Dougherty, T. J. 1976. Identification of singlet oxygen as the cytotoxic agent in photo-inactivation of a murine tumor. Cancer Res., 36, 2326-2329.

Wilkinson, F., Helman, W. P. \& Ross, A. B. 1995. Rate constants for the decay and reactions of the lowest electronically excited singlet state of molecular oxygen in solution. An expanded and revised compilation. J. Phys. Chem. Ref. Data, 24, 663-1021.

\title{
Raku hävimise mehhanismist hematoporfüriini derivaadi fotoergastamisel
}

\author{
Vladimir Tšekulajev, Igor Ševtšuk ja Ljudmila Tšekulajeva
}

On uuritud, kuidas hematoporfüriini derivaadi (HPD) poolt fotosensibiliseeritud lipiidide ja proteiinide kahjustamine mõjub plasma membraani tervik- 
likkusele, mitokondrite funktsioonile ja rakkude hävimisele. Ehrlichi astsiidse kartsinoomi (EAK) rakkude kiiritamine HPD manulusel pärssis glükolüüsi ja respiratoorset aktiivsust ning alandas oluliselt adenosiintrifosfaadi (ATP) taset rakkudes. HPD fotodünaamiline (FD) kahjustav toime rakkude energeetilisele metabolismile oli otseselt seotud rakkude vitaalsusega. Näiteks 20-minutisel kiiritamisel langes ATP tase $80 \%$ ning 98\% rakke hävis (MTT test). Samas teised HPD-FD toimeefektid, nagu trüpaansinise läbitavuse suurenemine, raku membraani ja raku morfoloogilised muutused (sopistuste teke raku pinnal) ilmnesid palju suurematel valgusdoosidel. Saadud tulemused näitavad, et lipiidide peroksüdatsiooni stimulatsioonil ei ole HPD fototoksilisus tähtis, kuna fotokiiritamisel tekkis küllastamata rasvhapetest oksüdatsiooniprodukte tühisel määral. Veelgi enam - rakusisese kolesterooli toime EAK rakkude HPD fototoksilisusele oli väike. Rakusisesed proteiinid on väga tundlikud HPD-FD toimele, sest trüptofaani, tsüsteiini ja histidiini tase rakkudes langes märgatavalt. HPD fotosensibiliseeritud proteiinide oksüdatsiooniga toimub tsütoplasma membraani vigastamine ja mitokondrite talituse inhibeerimine. Kogutud andmetest tuleneb, et raku valkudel on võtmeroll HPD fototoksilise toime puhul. 